\title{
Conf-720821--1
}

\section{EQUILIBRIUM DISTRIBUTION OF LITHIUM AND BISMUTH BETWEEN LIQUID Li-Bi ALLOYS AND MOLTEN LiCl AT 650 TO $800^{\circ} \mathrm{C} *$}

L. M. Ferris, M. A. Bredig, and F. J. Smith

Oak Ridge National Laboratory

Oak Ridge, Tennessee 37830

NOTICE

This report was prepared as an account of work sponsored by the United'States Government. Neither the United States nor the United States Atomic Energy

Commission, nor any of their employees, nor any of their contractors, subcontractors, or their employees,

makes any warranty, express or implied, or assumes any

makes any warranty, express or implied, or assumes any

pleteness or usefulness of any iniormation, apparatus,

product or process disclosed, or represents that its use

would not infringe privately owned rights.

For review by the Journal of Physical Chemistry and presentation at the 164th National American Chemical Society Meeting, New York, Aug. 27 - Sept. 1, 1972.

*Research sponsored by the U. S. Atomic Energy Commission under contract with the Union Carbide Corporation. 


\title{
EQUILIBRIUM DISTRIBUTION OF LITHIUM AND BISMUTH BETWEEN LIQUID
}

\section{Li-Bi ALLOYS AND MOLTEN LICl AT 650 TO $800^{\circ} \mathrm{C} *$}

\author{
L. M. Ferris, M. A. Bredig, and F. J. Smith \\ Oak Ridge National Laboratory \\ Oak Ridge, Tennessee 37830
}

\section{ABSTRACT \\ The distribution of lithium and bismuth between liquid $\mathrm{Li}-\mathrm{Bi}$ alloys and molien $\mathrm{LiCl}$} was measured at several temperatures between 650 and $800^{\circ}$. The extent of their distribution fo the $\mathrm{LiCl}$ increased at each temperature as the lithium concenfration in the alloy increased; for example, at $650^{\circ}$, the bismuth concentration in the $\mathrm{LiCl}$ increased from about 5 to 4800 p.p.m. as the lithium concentration in the alloy increased from 10 to 50 at. \%. The "free" lishium-to-bismuth ratio in the $\mathrm{LiCl}$ was 3 , suggesting that saltlike $\mathrm{Li}_{3} \mathrm{Bi}$ was distributing between the two phases. In a model describing this process, the species $\mathrm{Li}^{+}, \mathrm{Bi}^{3-}$, and $\mathrm{Bi}^{\circ}$ were assumed to be present in the alloy phase. The experimental data fit the model in that, at each temperature, a plot of $\log N_{\mathrm{Li}_{3} B i(d)}$ vs. $\log \left(\mathrm{N}_{\mathrm{Li}(\mathrm{m})}^{4}\left[3-\mathrm{N}_{\mathrm{Li}(\mathrm{m})}\right]^{-3}\left[3-3 \mathrm{~N}_{\mathrm{Li}(\mathrm{m})}\right]^{-1}\right)$ was linear with the expected unit slope. In these expressions, $N$, (d), and (m) denote mole fraction, dissolved in the salt phase, and dissolved in the alloy phase, respectively. Data obiained over the temperature range $650-800^{\circ}$ can be expressed as:

$\log N_{L i} B i(d)=\log \left(N_{L i(m)}^{4}\left[3-N_{L i(m)}\right]^{-3}\left[3-3 N_{L i(m)}\right]^{-1}\right)+0.7256-1086 / T\left(^{\circ} \mathrm{K}\right)$, with an estimated uncertainty in $\log \mathrm{N}_{\mathrm{Li}_{3} \mathrm{Bi}(\mathrm{d})}$ of \pm 0.05 . The data could also be accurately represented by a model in which random mixing of $\mathrm{Li}^{+}, \mathrm{Bi}^{3-}$, and $\mathrm{Bi}^{\circ}$ in the alloy phase was cosumed.

Research sponsored by the U. S. Atomic Energy Commission under contract with the Union Casbide Corporation. 


\section{INTRODUCTION}

A meial-iransfer process for separating rare-earth fission products from thorium is boinj Coveloped as one siep in the chemical processing of molten-salt breeder reaciors (MSBRE). In this process ${ }^{i, 2}$ some of the thorium and rare earths are extracted from the LiF-BeF $2-\mathrm{ThF}_{4}$

i. L. E. MaNeese, MSR Program Semiannu. Progr. Rep. Feb. 28, 1971, USAEC Rep. ORNL-4676, p. 234.

2. D. E. Fergusol. and Staff, Chem. Technol. Div. Annu. Progr. Rep. Mar. 31, 1971, USAEC Rep. ORNL-4682, p. 2.

carrier salt into a $\mathrm{Li}-\mathrm{Th}-\mathrm{Bi}$ solution and, then, the rare earths are selectively extracted into molten $\mathrm{LiCl}$. Finally, the rare earths are extracted from the $\mathrm{LiCl}$ by reductio: into a $\mathrm{Li}-\mathrm{Bi}$ solution in which the lithium concentration is 5 to 50 at. \%. The net result is the transfer of a large fraction of the rare earths, but only a very small fraction of the thorium, from the fluoride salt to $\mathrm{Li}-\mathrm{Bi}$ solutions of high lithium concentration. This separation is implicitly and significantly based on the reversal of the sequence of free energies of formation (per equivalent) of chlorides vs. fluorides of metal cations of varying polarizing power (di- and thipositive rare earths less than tetrapositive thorium) by virtue of the large difference in polarizabilities ${ }^{3}$ of the two anions, $\alpha\left(\mathrm{Cl}^{-}\right)=3.55 \AA^{3}$ and $\alpha\left(F^{-}\right)=0.97 \AA^{3}$.

3. M. A. Bredig; MSR Progräm Semiannu. Progr. Rep. Aug. 31, 1970, USAEC Rep. ORNL-4622, p. 85. 
Rustis from the initial resis of the metal-transfer process indicated that, when molten LCl wis confacted with liquid Li-Bi allicys at about $650^{\circ}$, the distribution of both "rree" Viribium "and of bismuth to the salt phase was significant. "This behavior was not entirely:

4. E. L. Youngblood and L. E. McNeese, MSR Program Semiannu. Frogr. Rep. Aug. 31, 7971, USAEC Rep. ORNL-4728, p. 202.

unexpected since $\mathrm{Li}_{3} \mathrm{Bi}$ is quite soluble in $\mathrm{LiCl}-\mathrm{LiF}$ (70-30 mole \%), and the distribution of lithium and bismuth to this salt phase is significant when the sali is in contact with liquid $\mathrm{Li}-\mathrm{Bi}(50-50$ at. $\%)$ at 650 to $1000^{\circ} .{ }^{5,6}$ We have investigated the equilibrium distribution

5. M. S. Foster, C. E. Crouthamel, D. M. Gruen, and R. L. McBeth, J. Phys. Chem. $68,980(1964)$.

6. E. J. Cairns, C. E. Crouthamel, A. K. Fischer, M. S. Foster, J. C. Hesson, C. E. Johnson, H. Shimotake, and A. D. Tevebaugh, Galvanic Cells with Fused-Salt Electrolytes, USAEC Rep. ANL-7316, (1967), p. 119.

of lithium and bismuth beiween liquid $\mathrm{Li}-\mathrm{Bi}$ alloys and molten $\mathrm{LiCl}$ in the temperature range $650-800^{\circ}$, and have summarized the results in this paper.

\section{EXPERIMENTAL}

Reagenfs. - Reagent-grade $\mathrm{LiCl}$ was oven-dried at about $120^{\circ}$ before use. Analyses of the salt afier melfing under high-purity argon showed that the LiOH content was less than 0.05 
no \% \% ine bismuth was Cominco American Co. 69 grade. Necessary amounis of lithium weve cut uncier oil from reagentagrade siock and were washed with benzene just prior to use. Migh mpurity argon was further ireaied by passage through a Molecular Sieve frap and a firanium sponge trap that was held ar $600^{\circ}$.

Procedure. - Equilibrations were conducted in an argon atmosphere, using the apparatus cind general procedure described previously. ${ }^{7}$ About $125 \mathrm{~g}$. of $\mathrm{LiCl}$ and a total of $100 \mathrm{~g}$.

7. L. M. Ferris, J. C. Mailen, J. J. Lawrance, F. J. Smith, and E. D. Nogueira, J. Inorg. Nucl. Chem. 32, 2019 (1970).

of the desired amounis of lithium and bismuth were loaded into a molybdenum crucible. After the crucible had been sealed in the containment vessel, the system was heated to the desired temperature in an atmosphere of pure argon. After reaching this temperaturc, the system was allowed to equilibrate for at least $24 \mathrm{hr}$. before samples of the respective phases were taken. Molybdenum pipettes were used to obtain 2- to $15-\mathrm{g}$. samples of the salt phase, whereas samples of the alloy phase were taken with stainless steel filter sticks. The color of quenched samples of the salt changed from nearly snow-white to a deep red-brown as the lithium concentration in the alloy was increased from about 10 to 50 at. $\%$.

One experiment was conducted to defennine the solubility of $\mathrm{Li}_{3} \mathrm{Bi}$ in $\mathrm{LiCl}$ over the temperature range $650-800^{\circ}$. In this experiment, the lithium concentration in the alloy was 70 at. \%. According to the Bi-Li phase diagram, ${ }^{8}$ this gives a two-phase equilibrium 


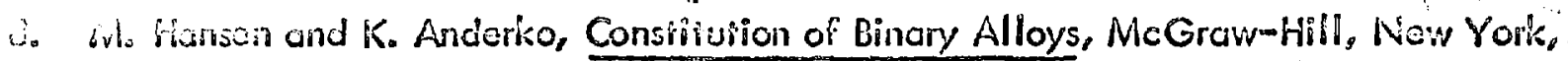
$\$ 958$, p. 370.

wabiurs of solid $L_{3} B i$ and a liquid $L i-B i$ alloy in which the lithium concentration varies thon dbout 52 to 62 at. \% as the femperature increases from 650 io $800^{\circ}$. It is important io realize that with its solid phase as the standard state, the $\mathrm{Li}_{3} \mathrm{BI}$ in the mixture is at unit activiviy. The temperaiure of the system was randomly varied between 650 and $800^{\circ}$. At least $24 \mathrm{hr}$. was allowed for aftainment of equilibrium at each temperature before several samples of the sali phase were removed for analysis. The quenched salt samples had a very cieep red-brown color.

Analyses. - The salt samples were analyzed for "free" lithium and for bismuth by, first, Lydrolyzing the samples in water and collecting the evolved hydrogen on a Molecular Sieve column at liquid nitrogen temperaiure. After hydrolys: was complete, the hydrogen was eluied from the colunn with helium and the amount eluted was determined by gas chromaiography. The amount of hydrogen evolved was assumed to be equivalent to the cimount of "free" lithium in the salt. The hydrolysis residue was then acidified to ensure finat all of the bismuth was in solution. Aliquots of this solution were used for the determinution of the bismuth concentration. When the bismuth concentration in solution was cquivalenif to a concentration of 100 p.p.m. or greater in the salt, the analysis was made using the specirophotometric iodide method for bismuth. When bismuth was present af lower concenirarions, it was determined by an inverse-polarographic method. The lithium con-: ceniraiions in alloy samples were determined by flame-photometry. 


\section{RESULTS}

tho cguilibriun concentrations of bismutin and lithium, expressed as mole fracions (IV).

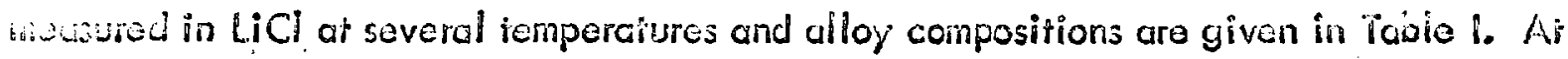
Wois femperciure the concontrations of these elemenis in the LiCl increased ciromatically us the lithium concentration in the cllloy $\left[\mathrm{N}_{\mathrm{Li}(\mathrm{m})}\right]$ was increased. Also, the mole ratio of "Gree" lihhium io bismuth dissolved in the salt phase, i.e., $\mathrm{N}_{\mathrm{Li}(\mathrm{dj})} / \mathrm{N}_{\mathrm{Bi}(\mathrm{d})}$, was chout 3 in most cases. However, in some cases, the indicated ratio was much lower than 3 . These latier resulis are probably spurious because of the inhert difficuliy in obtaining accurate values for the "free" lithium concentration by the method employed. With the apparatus used, the hydrogen evolved auring hydrolysis of a salt sample could be retained quantitatively on the Molecular Sieve column for only 15 to $20 \mathrm{~min}$. When hydrolysis was slow (cs, for example, with samples that were large), some loss of hydrogen from the system could have occurred. Consequently, the apparent value of $\mathrm{N}_{\mathrm{Li}(d)} / \mathrm{N}_{\mathrm{Bi}(\mathrm{d})}$ would be low. Analysis of salt samples that were contaminated with entrained Li-Bi alloy would also give a low value for the ratio $N_{L i(d)} / N_{B i(d)}$ : The preponderance of the information indicates that, within experimental uncertainty, the value of $\mathrm{N}_{\mathrm{Li}(\mathrm{d})} \mathrm{N}_{\mathrm{Bi}(\mathrm{d})}$ was 3.

The values determined for the solubility of $\mathrm{Li}_{3} \mathrm{Bi}$ in molten $\mathrm{LiCl}$ over the temperature range $650-800^{\circ}$ are given in Table II. These data also indicate that $N_{L i(d)} / N_{B i(d)}$ was 3. In Figure 1, the data are compared with the values obtained by Foster ef al. ${ }^{5}$ over the temperature range $650-1000^{\circ}$ using $\mathrm{LiCl}-\mathrm{LiF}(70-30$ mole \%) as the salt phase. Wirhin analyifical unceriainty, the solubility of $\mathrm{Li}_{3} \mathrm{Gi}$ was the same in both salt phases. The data can be represented by log S(mole \%) $=\left[3.437-4110 / T\left({ }^{\circ} \mathrm{K}\right)\right] \pm 0.00$. 
Toblo 1: Daiu Obrained by Equilibrating Liquid Li-Bi Alloys with

Motien LiCl ci vicrious femperaiures

\begin{tabular}{|c|c|c|c|c|c|c|}
\hline$\because \therefore$ & $\begin{array}{c}\text { Tenop. } \\
(00)\end{array}$ & $N_{H E(i n)}$ & $10^{\circ} \mathrm{N}_{\mathrm{Bi}(\mathrm{d})}$ & $10^{\circ} \mathrm{N}_{\operatorname{li}(\mathrm{d})}$ & & $N_{\text {Li(u) }} N_{\text {Li(j) }}$ \\
\hline$\tilde{i}$ & 050 & $0.093 i$ & $0.72 \pm 0.05$ & $6.9 \div 3$ & & $8.7 \div 4$ \\
\hline 2 & & 0.175 & $i .5 \pm 0.3$ & $19 \pm 10$ & 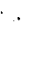 & $13+5$ \\
\hline 3 & & 0.104 & $6.3 \pm 2$ & $29 \pm 4$ & ; & $4.3=2.5$ \\
\hline 4 & & 0.213 & $12.3 \pm 2$ & $63 \pm 15$ & & $5.0 \pm 1.7$ \\
\hline .5 & & 0.224 & $21.8 \pm 1$ & $B 3.4 \pm 5$ & & $3.8=0.5$ \\
\hline$\dot{0}$ & & 0.230 & $16.5 \pm 1$ & $43 \pm 8$ & & $2.8 \pm 0.8$ \\
\hline 3 & & 0.249 & $37.6 \pm 4$ & $126 \pm 50$ & & $3.4 \pm 1.4:$ \\
\hline 3 & & 0.249 & $22.1 \pm 2$ & $-\infty$ & & $-\infty$ \\
\hline 9 & & 0.263 & $45.6 \pm 15$ & $184 \pm 40$ & & $4.0 \pm 1.6$ \\
\hline 10 & & 0.292 & $47.3 \pm 3$ & $279 \pm 75$ & & $5.9 \pm 1.5$ \\
\hline 88 & & 0.371 & $67.3 \pm 14$ & - & & -- \\
\hline 12 & & 0.326 & $92.6 \pm 10^{\circ}$ & - & & - \\
\hline 13 & . & 0.376 & $202 \pm 8$ & $824 \pm 100$ & & $4 . i \pm 0.5$ \\
\hline 14 & ' & 0.381 & $205 \pm 3$ & $662 \pm 100$ & & $3.2 \pm 0.5$ \\
\hline 15 & & 0.392 & $211 \pm 13$ & $775 \pm 90$ & & $3.7 \pm 0.7$ \\
\hline 16 & & 0.399 & $263 \pm 2$ & $820 \pm 50$ & & $3.1 \pm 0.2$ \\
\hline 17 & & 0.475 & $505 \pm 55$ & $1580 \pm 200$ & & $3.1 \pm 0.4$ \\
\hline 18 & & 0.482 & $864 \pm 95$ & - & & - \\
\hline i9 & 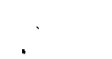 & 0.485 & $975 \pm 225$ & $2540 \pm 215$ & & $2.6 \pm 1$ \\
\hline 20 & & 0.487 & $649 \pm 40$ & $2945 \pm 630$ & & $4.5 \pm 1.3$ \\
\hline 21 & & 0.496 & $858 \pm 5$ & -- & & $-\infty$ \\
\hline 22 & 700 & 0.166 & $4.8 \pm 1$ & $23 \pm 1$ & & $4.7 \pm 1.2$ \\
\hline 23 & & 0.230 & $24.9 \pm 1$ & $67.7 \pm 1.2$ & & $2.7 \pm 0.2$ \\
\hline 24 & & 0.290 & $63.3 \pm 3$ & $186 \pm 10$ & & $2.9 \pm 0.3$ \\
\hline 25 & & 0.376 & $259 \pm 40$ & $757 \pm 85$ & & $2.9 \pm 0.3$ \\
\hline 25 & & 0.399 & $324 \pm 10$ & $920 \pm 15$ & & $2.8 \pm 0.2$ \\
\hline 27 & & 0.451 & $730 \pm 60$ & $1230 \pm 185$ & & $1.7 \pm 0.5$ \\
\hline 23 & & 0.487 & $832 \div 60$ & $3395 \pm 100$ & & $4.1 \pm 0.5$. \\
\hline 29 & 750 & 0.237 & $20.7 \pm 1$ & $78.4 \pm 9$ & . & $2.9 \pm 0.5$ \\
\hline 30 & & 0.290 & $74.8 \pm 6$ & $163 \pm 18$ & & $2.2 \pm 0.5$ \\
\hline $3 i$ & $\cdots$ & 0.399 & $410 \pm 10$ & $969 \pm 12$ & & $2.4 \pm 0.3$ \\
\hline 32 & & 0.487 & $1122 \div 60$ & $3827-275$ & & $3.4 \div 0.5$ \\
\hline 33 & 800 & 0.186 & $7.6 \pm 1$ & $8.7 \pm 0.2$ & 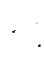 & $1.1 \pm 0.31$ \\
\hline 3 & $:^{\prime}$ & 0.244 & $27.5 \div 3$ & 89.3 ś & $\therefore$ & $3.0 \pm 0.6$ \\
\hline 53 & & 0.2350 & $89.0 \pm 4$ & $\because 177 \pm 36$ & $\because$ & $2.0 \pm 0.5$ \\
\hline 35 & $\therefore$ & 0.398 & $487 \pm 15$ & $944 \pm 40$ & $\because$ & $1.9 \div 0.2$ \\
\hline
\end{tabular}


ORNL DWG 72-6075

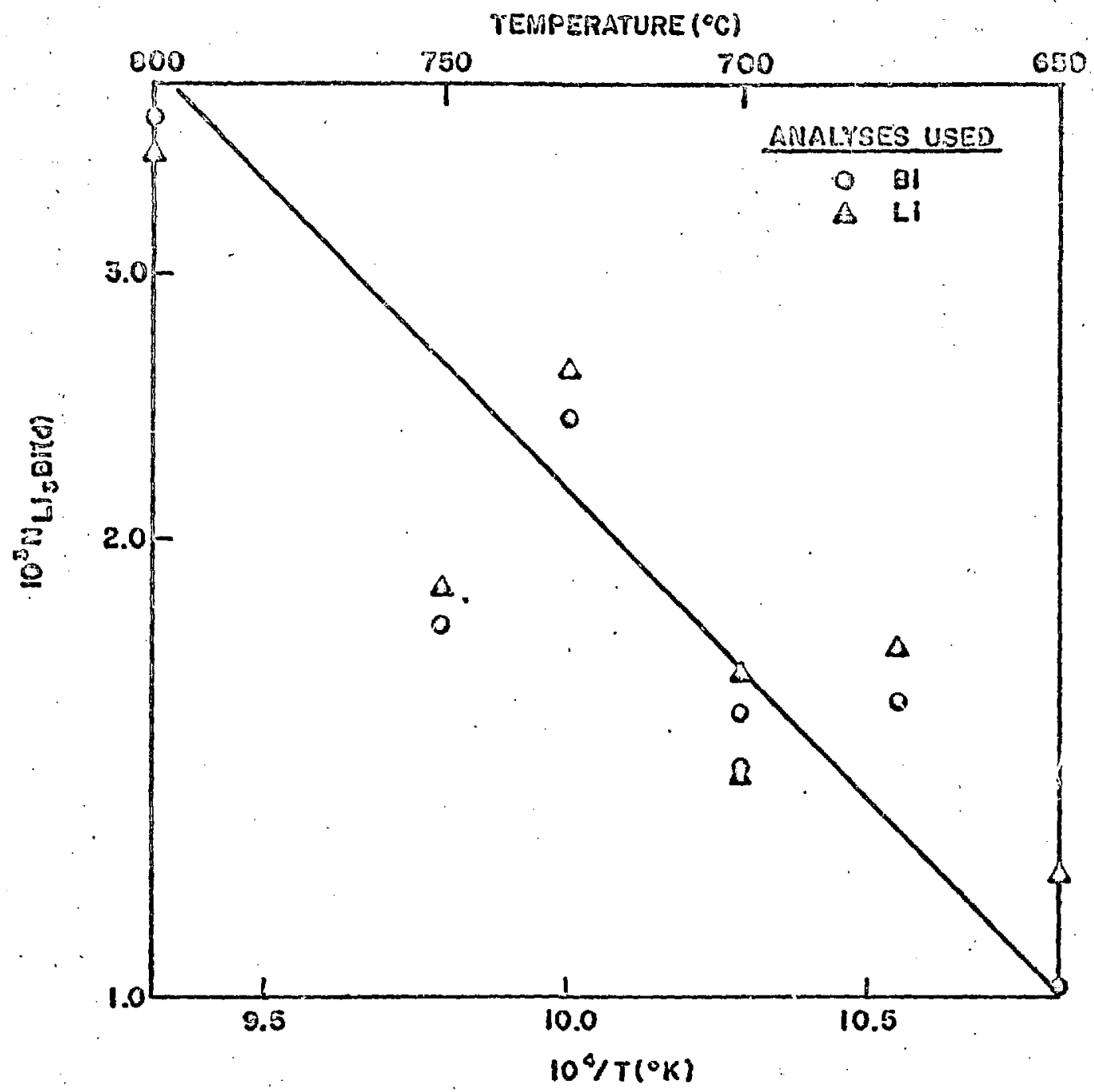

SOLUBILITY OF Li3 ${ }_{3}$ i IN MOLTEN LI REPRESENTS DATA OBTAINED BY FOSTER Qf aI." WITH MOLTEN LICR-LIF (70-30 MOLE \%).

Figuie 1. 


\section{DISCUSSION OF RESULTS}

The equilibrium bismuth concentrations in LiCI deformined in this investigation with Cinoi $\mathrm{Ij}_{3} \mathrm{Bi}$ or $\mathrm{Li}-\mathrm{Ei}$ (about 50-50 at. \%) as the metal phase are almosi identical to those coldined ar Argonne National Laboraiory (ANL) ${ }^{5,6}$ with LiCl-LiF (70-30 mole \%) as the saif phase. Hiowever, our value of about 3 for the $\mathrm{N}_{\mathrm{Li}(\mathrm{d})} / \mathrm{N}_{\mathrm{Bi}(\mathrm{d})}$ mole ratio over a wide range of alloy compositions and temperaiures does noi agree with the ANL results, ${ }^{6}$ which inalicaie tnat this ratio was befween 1 and 2 when the alloy was $\mathrm{Li}-\mathrm{Bi}(50-50$ at. \%). This disparity in results is presently inexplicable. Based on the information presented cisove, it would appear that the difference in results cannot be attributed to the use of LiCl-LiF insiead of LiCl as the salt phase.

Table 11. Solubility of $\mathrm{Li}_{3} \mathrm{Bi}$ in Molten $\mathrm{LiCl}$ in the Temperature Range $650-300^{\circ}$

\begin{tabular}{llcc}
$\begin{array}{l}\text { Temp. } \\
\left({ }^{\circ} \mathrm{C}\right)\end{array}$ & $10^{6} \mathrm{~N}_{\mathrm{Bi}(\mathrm{d})}$ & $10^{6} \mathrm{~N}_{\text {Li(d) }}$ & $\mathrm{N}_{\text {Li(d) }} / \mathrm{N}_{\text {Bi(d) }}$ \\
\hline 650 & $1035 \pm 100$ & $3720 \pm 40$ & $3.6 \pm 0.4$ \\
675 & $1570 \pm 35$ & $5160 \pm 390$ & $3.3 \pm 0.3$ \\
700 & $1550 \pm 10$ & $4935 \pm 365$ & $3.2 \pm 0.3$ \\
700 & $1410 \pm 15$ & $4205 \pm 165$ & $3.0 \pm 0.2$ \\
725 & $2420 \pm 55$ & $7805 \pm 350$ & $3.2 \pm 0.2$ \\
750 & $1760 \pm 10$ & $5610 \pm 870$ & $3.2 \pm 0.5$ \\
800 & $3815 \pm 450$ & $10810 \pm 1000$ & $2.8 \pm 0.7$ \\
\hline
\end{tabular}

The resulis obtained in the present study cannot be explained by the distribution beiween the iwo phases of lithium and bismuth per se. The solubility of biswutis in molten Lid is exiremely low, only about 0.1 p.p.m. at $650^{\circ} .^{9}$ Estimates based on the measured 
S. Lo Mo Ferris and J. Fo Land, MSR Fr̈gram Semiannu. Progr. Rep. Aug. 31, i97, USAEC RCP. ORNL -4723, p. 192.

Ceisviticis of fithium in liquid Li-Bi alloys ${ }^{10}$ and the solubility of lithium in molien LiCl

W. M. S. Fosier, S. E. Wood, and C. E. Crouthamel, !norg. Chem. 3, 1428 (1964).

i]. A. S. Uworkin, H. R. Bronsiein, and M. A. Bredig, J. Phys. Chem. 66, 572 (1962).

show that the equilibrium lithium concentrations in $\mathrm{LiCl}$ would be insignificant in comparison with those detemined experimentally. If lithium per se distributed between the two phases, a likciy equilibrium involved ${ }^{12}$ would be.

$$
2 L i_{(m)}=L i_{2(d)} \text { : }
$$

12. M. A. Bredig, "Mixtures of Metals with Molten Salts." in M. Blander (ed.), Molten Sali Chemistry, Interscience Publishers, New York, 1964, p. 367.

in which $(\mathrm{m})$ and $(\mathrm{d})$ denote the alloy and $\mathrm{LiCl}$ phases, respectively. Since the lithium acrivity in each phase is the same, it can be easily shown that

$$
N_{L i(d)}=\frac{2 N_{L i(m)}^{2} \gamma_{m}^{2}}{\gamma_{d}},
$$

in which $\gamma_{\mathrm{d}}$ and $\gamma_{\mathrm{m}}$ are activity coefficients referred to pure liquid lithium as the standard sicie. Using vaives of $\gamma_{d}$ estimated from the solubility data of Dworkin es al. ${ }^{11}$ and of 


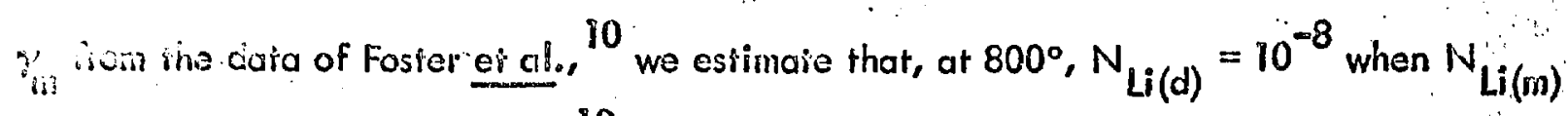
is 0.5 and that $N_{L i(d)}$ is $2 \times 10^{-12}$ when $N_{L i(m)}$ is 0.1 . These values are negligible when cumpared with the values obrained experimentally (Table 1). This conclusion is also valid. fo: temperairures lower than $800^{\circ}$. As a consequence, we conclude that the experimental rosslis are best interpreted in terms of the distribution of saltlike $\mathrm{Li}_{3}$ Bi between the two pheses.

Several models describing the distribution of $\mathrm{Li}_{3} B \mathrm{~B}$ befween a liquid $\mathrm{Li}-\mathrm{Bi}$ alloy and motien $\mathrm{LiCl}$ were tested. The most accurate representation of the data was obtained using mociels in which the species $\mathrm{Li}^{+}, \mathrm{Bi}^{3-}$, and $\mathrm{Bi}^{\circ}$ were assumed to be present in the alloy by virtue of the reaction

$$
3 \mathrm{Li}^{\circ}+B \mathrm{i}^{\circ} \rightarrow 3 \mathrm{Li}^{+}+B \mathrm{i}^{3-},
$$

and by defining concentrations in terms of ion fractions. In one model, which gave an excellent representation of the data, the ion fractions of $\mathrm{Li}^{+}$and $\mathrm{Bi}^{3-}$ were defined as

$$
x_{\mathrm{Li}^{+}}=\frac{n_{\mathrm{Li}^{+}}}{\mathrm{n}_{\mathrm{Li}^{+}}+\mathrm{n}_{\mathrm{Bi}}{ }^{\circ}}
$$

and

$$
x_{\mathrm{Bi}^{3-}}=\frac{{ }_{\mathrm{Bi}^{3-}}}{{ }_{\mathrm{Li}^{+}}{ }^{+} n_{\mathrm{Bi}}{ }^{\circ}}
$$

in which $n$ denotes number of moles. It should be noted that $n_{B i}$ is the number of moles of $\mathrm{Bi}^{\circ}$. present in the alloy after reaction (3) has occurred, and that these definitions of ion fraction can be applied only when the mole fraction of lithium is 0.75 or less. The Coivivities of $\mathrm{Li}_{3} \mathrm{Bi}$ in the salt and alloy phases are defined, respectively, as 


$$
a_{L_{3} B i(m)}=\left[x_{L i^{+}}^{3}\right]\left[x_{B i 3-3}\right]\left[\gamma_{L_{3} B i(m)}\right]
$$

and

$$
a_{L_{3} B i(d)}=N_{L_{3} B i(d)} \gamma_{L_{3} B i(d)} .
$$

When the $\mathrm{Li}_{3} \mathrm{Bi}$ concentration in the $\mathrm{LiCl}$ is low, $\mathrm{Eq}$. (7) can be written as

$$
a_{L_{3} B i(d)}=N_{B i(d)} \gamma_{L_{3} B i(d)}=\left[N_{L i(d)}{ }^{3}\right] \gamma_{L_{3} B i(d)},
$$

in which $N_{B i(d)}$ and $N_{L i(d)}$ are the measured mole fractions of bismuth and "free" lithium in the $\mathrm{LiCl}$. Since the activity of $\mathrm{Li}_{3}{ }^{\mathrm{Bi}}$ is the same in each phase at equilibrium at a given Remperature, Eqs. (6) and (8) can be equated. After appropriate substitutions and rearrangemenis, we obiain, in logarithmic form:

$\log N_{B i(d)}=\log \left[N_{L i(d)} / 3\right]=\log \left[\frac{N_{L i(m)}^{4}}{\left(3-N_{L i(m i)}\right)^{3}\left(3-3 N_{L i(m)}\right)}\right]+\log \Gamma$.

in which $N_{L i(m)}$ is the mole fraction of lithium in the alloy. For simplicity, we will write Eq. (9) as

$$
\log N_{B i(d)}=\log \left[N_{L i(d)} / 3\right]=\log \bar{\Phi}+\log \Gamma
$$

If the ratio of the activity coefficients, $\gamma_{\mathrm{Li}_{3} \mathrm{Bi}(\mathrm{d})} / \gamma_{\mathrm{Li}_{3} \mathrm{Bi}(\mathrm{m})^{\prime}}$ is constant at a given temperature, $T$ is alsc constani and a plor of $\log N_{B i(d)}$ or $\log \left[N_{L i(d)} / 3\right]$ vs. $\log \tilde{\varphi}$ would yield a line of unis slope.

Plots of $\log \left[10^{6} \mathrm{~N}_{\mathrm{Bi}(\mathrm{d})}\right]$ and $\log \left[10^{6} \mathrm{~N}_{\mathrm{Li}(\mathrm{d})} / 3\right]$ vs. $\log \tilde{\Phi}$ are shown in Figures 2 and 3. The lines, which are the best least-squares lines of unit slope, were derived from the bismuth concentrations because these could be determined analytically with more accuracy 


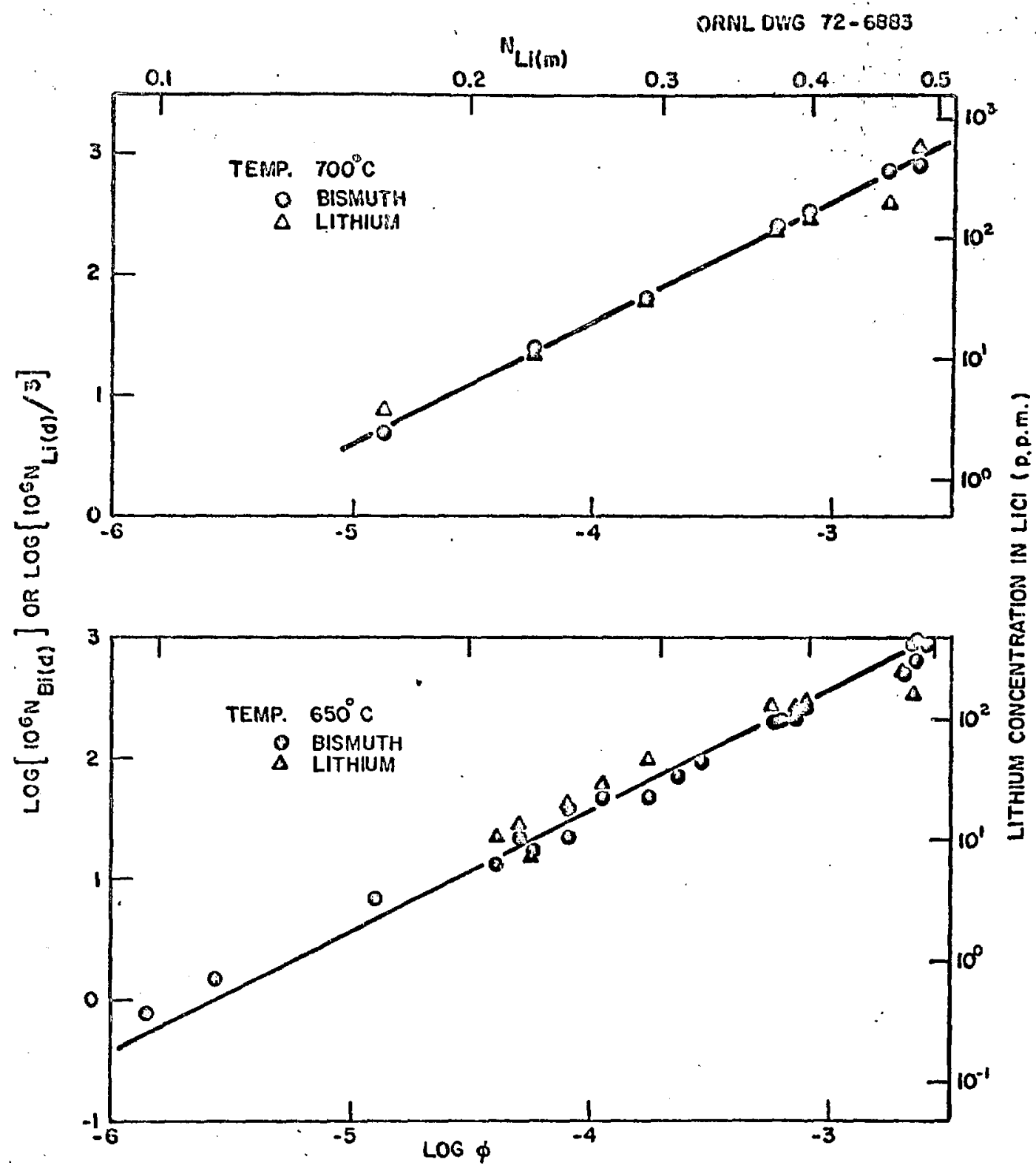

- EOUILIBRIUM DISTRIBUTION OF LITHIUM AND EISMUTH BETWEEN LIQUID LI-BI ALLOYS AND MOLTEN LICI AT $650^{\circ} \mathrm{C}$ AND $700^{\circ} \mathrm{C}$.

Figure 2. 
ORNL OWG $72-6800$

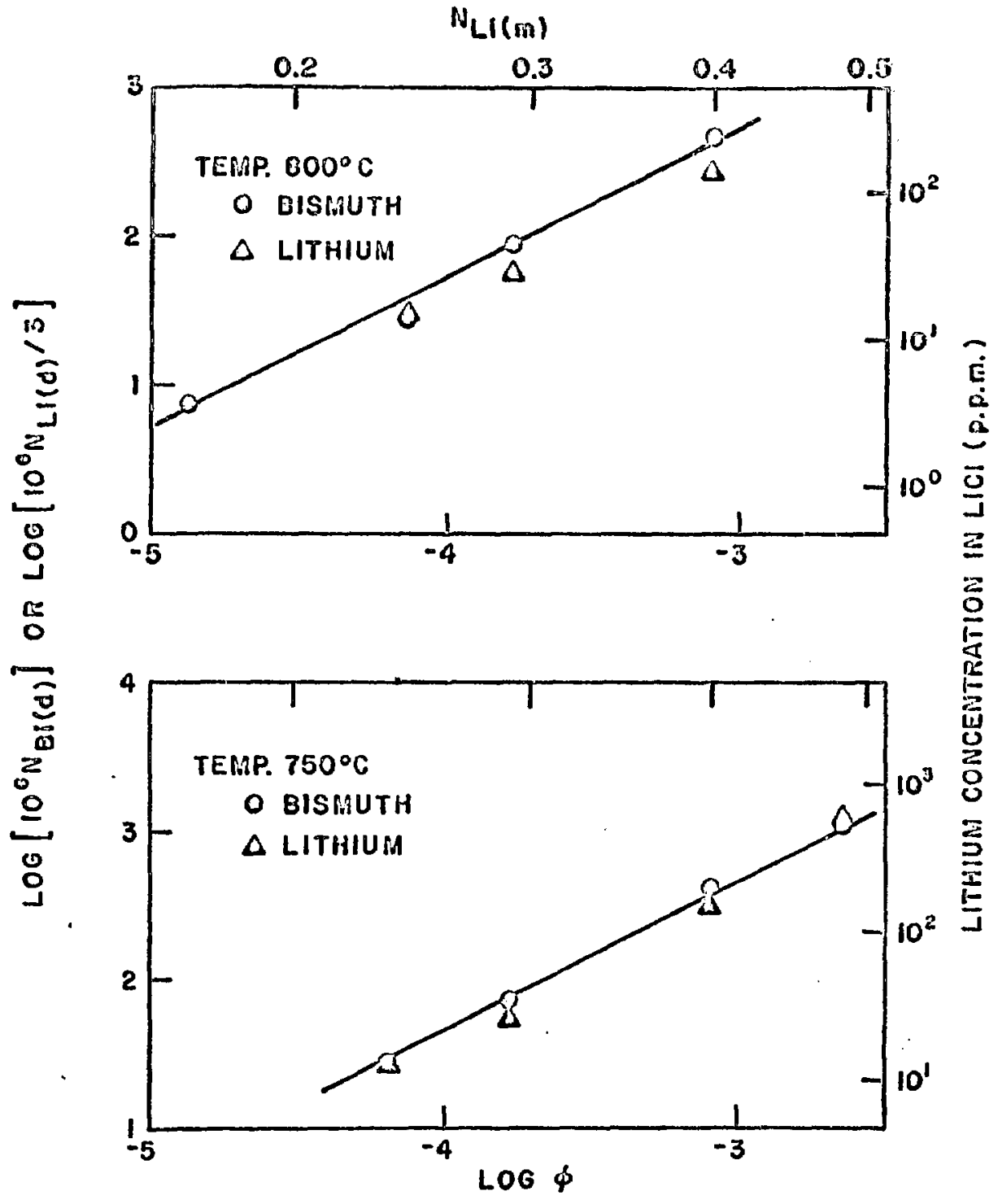

EQUILIBRIUM OISTRIBUTION OF LITHIUM AND BISMUTH BETWEEN LIQUID Li-Bi ALLOYS AND MOLTEN LICI AT $750^{\circ}$ AND $800^{\circ} \mathrm{C}$.

Figure 3. 
initit she fibium concentrations in the LiCl. Actually, placement of the lines using the Ifivivia analyses would not give markedly different results, particularly ai $650^{\circ}$ and $700^{\circ}$. As seci in figures 2 and 3 , the above model represents the experimental daia very well. The cosson for this is not obvious because the definitions of the ion fractions for $\mathrm{Li}^{+}$and Gi ${ }^{-}$- Eqs. (4) and (5), are unusual and are not easily related to a simple statistical model for the mixing of the various species in the alloy. ${ }^{13}$ The fact that the data at each

13. J. Braunstein, "Statistical Thermodynamics of Molten Salts and Concentrated Aqueous Electrolytes." In S. Petrucci (ed.), lonic Interactions, Vol. I, p. 180, Academic Press, New York, 1971.

iomperature obeyed Eq. (9) showed that the activity coefficient ratio $\gamma_{\mathrm{Li}_{3} \mathrm{Bi}(\mathrm{d})} / \gamma_{\mathrm{Li}_{3} \mathrm{Bi}(\mathrm{m})^{\prime}}$ and hence $\Gamma$, was constant over a wide range of concentrations. Values of $\Gamma$ obtained from the respective isotherms vere:

\begin{tabular}{|c|c|}
\hline $\begin{array}{l}\text { Temp. } \\
\left({ }^{\circ} \mathrm{C}\right)\end{array}$ & $\Gamma$ \\
\hline 650 & $0.35 \pm 0.08$ \\
\hline 700 & $0.40 \pm 0.03$ \\
\hline 750 & $0.46 \pm 0.04$ \\
\hline 800 & $0.52 \div 0.08$ \\
\hline
\end{tabular}

The dara obiained in the femperalure ranga $650-800^{\circ}$ can be expressed as:

$$
\log N_{B i(d)}=\log \left[N_{L i(d)} / 3\right]=\left[\log \ddot{\varphi}+0.7256-1086 / T\left({ }^{\circ} \mathrm{K}\right)\right] \pm 0.05
$$


inciependent estimates of I can be made using the measured solubilities of $\mathrm{Li}_{3} \mathrm{Gi}$ in wolien LiCl and the liquidus curve from the Bi-li phase diagram if the standard siate for "I ${ }_{3} \mathrm{Li}$ is chosen as the pure solid. If yo cissume that $\gamma_{L_{i}} B i(d)$ is not a function of the Liji concentration in $\mathrm{LiCl}$ at each temperature, its value is simply the reciprocal of the soivbilify of $\mathrm{li}_{3} \mathrm{Bi}$ in $\mathrm{LiCl}$ at that temperature. This assumption seems rasoncible because live solubilities of $\mathrm{Li}_{3} \mathrm{Bi}$ in molien $\mathrm{LiCl}$ are low over the temperature range being considered. Fion the data presented in Table $\|$ and Figure 1, we obtain log $\gamma_{L_{3} B i(d)}=[-1.437$ $\left.\div 4110 / T\left({ }^{\circ} \mathrm{K}\right)\right] \pm 0.06$. In deriving Eq. (9), it will be found that

$$
\log I=\log \left[27 \gamma_{L_{3} B i(m)}\right]-\log \gamma_{L_{3} B i(d)}=-\log \bar{\Phi}-\log \gamma_{L_{3} B i(d)} .
$$

Experimentally, it was shown that $\Gamma$ was a constant at a given temperaiure; thus, if our cissumption regarding the constancy of $\gamma_{\mathrm{Li}_{3} \mathrm{Bi}(\mathrm{d})}$ is valid, $\gamma_{\mathrm{Li}_{3} \mathrm{Bi}(\mathrm{m})}$ would also be a constant at each temperature. It can be shown from Eq. ( 6 ; that $\bar{\Phi}^{-1}=27 \gamma_{\mathrm{Li}_{3} \mathrm{Bi}(\mathrm{m})}$ when $a_{L_{3} B i(m)}=$ ?. Using the $B i-L i$ phase dicgram, ${ }^{8}$ values of $\Phi^{-1}$ were calculated for the liquid alloys in equilibrium with solid $\mathrm{Li}_{3} B \mathrm{i}$ at several selected temperatures. These values ware used in conjunction with the appropriate values of $\gamma_{\mathrm{Li}_{3} \mathrm{Bi}(\mathrm{d})}$ to estimate $\Gamma$ at these temperatures. The values obtained are given in Table III, and are compared with the experimentally determined values in Figure 4. Considering the limits of uricertainiy, the cgreement is good.

The dala obtained $\mathrm{b}_{;}$Okada er al. ${ }^{14}$ for the distribution of sodium and bismuth between 14. M. Okado, R. A. Guidotri, and J. D. Corbett, Inorg. Chem. Z, 2118 (1968). 
ORNL DWG. $72-6303$

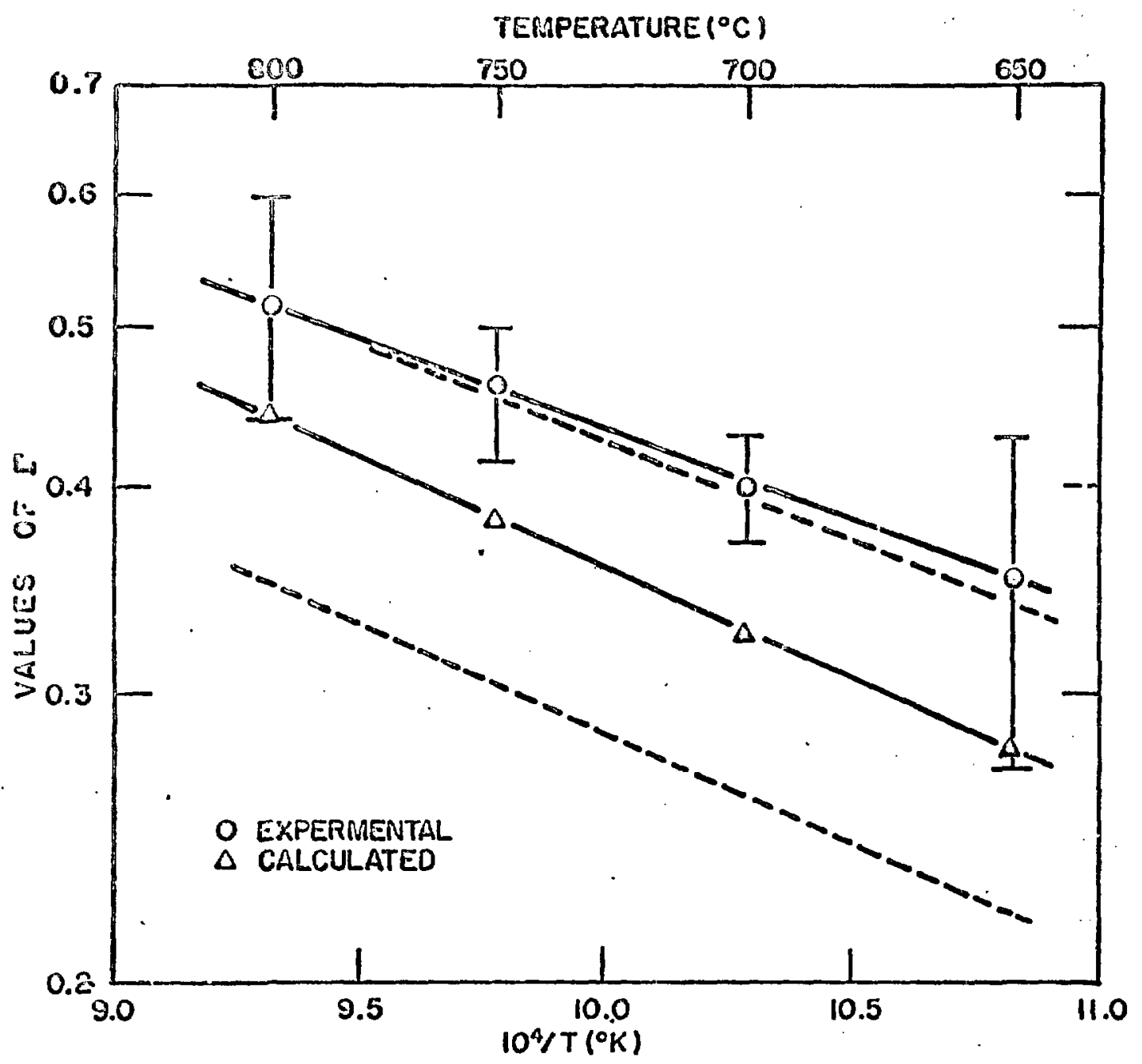

COMPARISON OF EXPERIMENTALLY DETERMINED AND

CALCULATED VALUES OF $\Gamma$. THE DASHED LINES REPRESENT THE LIMITS OF UNCERTAINTY IN THE CALCULATED VALUES.

Figure 4. 
Table llit: Values of I' Calculared from $\mathrm{Li}_{3}$ Bi Solubility Daka and the Bi-li Phase Diagram

\begin{tabular}{|c|c|c|c|c|c|}
\hline $\begin{array}{l}\text { Tomps. } \\
00\end{array}$ & $N_{L i(m)}$ & $\log \gamma_{L_{3}} B i(d)$ & $-\log \hat{\theta}$ & $\log I$ & I \\
\hline 050 & $0.524 \pm 0.01$ & $3.01 \pm 0.06$ & $2.457 \pm 0.07$ & $-0.550 \pm 0.09$ & $0.2 B \pm 0.06$ \\
\hline 700 & $0.558 \pm 0.01$ & $2.79 \pm 0.06$ & $2.301 \pm 0.07$ & $-0.486 \pm 0.09$ & $0.33 \pm 0.06$ \\
\hline 750 & $0.588 \pm 0.01$ & $2.58 \pm 0.00$ & $2.164 \pm 0.07$ & $-0.416 \pm 0.09$ & $0.33 \pm 0.08$ \\
\hline 300 & $0.610 \pm 0.01$ & $2.39 \pm 0.06$ & $2.036 \pm 0.07$ & $-0.354 \pm 0.09$ & $0.44 \pm 0.09$ \\
\hline
\end{tabular}

fiquid $\mathrm{Na}-\mathrm{Bi}$ alloys and molten $\mathrm{NaCl}-\mathrm{Nal}$ (37-63 moia \%) over the temperature range $600-1000^{\circ}$ are represented excellently by the model described above. Consequently, we would concur with their conclusion that the observed resulis were due primarily to the disiribution of $\mathrm{Na}_{3} \mathrm{Bi}$ between the two phases and that the effect of $\mathrm{NaBi}$ was small. If should also be noted that the representation of their data by our model is much better than that obtained using a quasi-ideal model ${ }^{15}$ involving ideal solutions of the assumed species

15. A. K. Fischer, S. A. Johnson, and S. E. Wood, J. Phys. Chem. 7I, 1465 (1967).

$\mathrm{Na}, \mathrm{Bi}, \mathrm{NaBi}$, and $\mathrm{Na}_{3} \mathrm{Bi}$.

The experimental data obtained in the present investigation could also bo represented accurately by a model involving random mixing of $\mathrm{Li}^{+}, \mathrm{Bi}^{3-}$, and $\mathrm{Bi}^{\circ}$ in the alloy phase. With random mixing, the respective ion fractions are

$$
X_{\mathrm{Li}^{+}}=\frac{n_{\mathrm{Li}^{+}}}{n_{\mathrm{Li}^{+}}+n_{\mathrm{Bi}}{ }^{3-}+n_{3 i^{\circ}}}=N_{\mathrm{Li}(\mathrm{m})}
$$




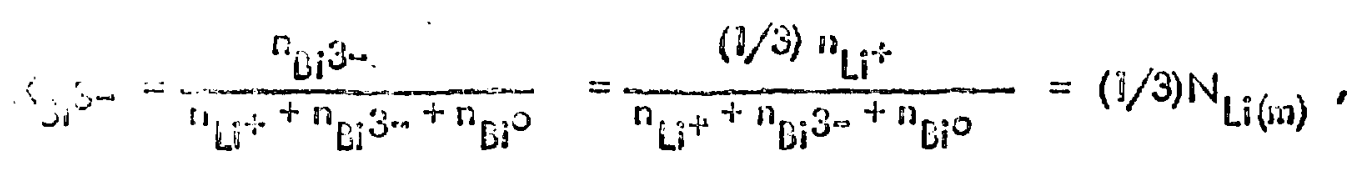

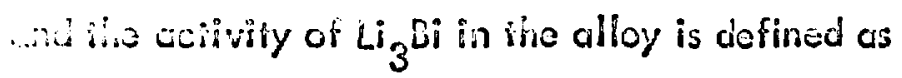

$$
\left.c_{L_{3} B i(m)}=\left[x_{L i}^{3}\right] C X_{B i} 3^{3-a}\right]\left[\gamma_{L i_{3} L i(m)}^{3}\right]=(1 / 3)\left[N_{L i(m)}^{4}\right]\left[\gamma_{L i_{3} B i(m)}^{\prime}\right] .
$$

Using tho same definition for the activity of $\mathrm{Li}_{3} \mathrm{Bi}$ in the sali phase as was used above [Eq. (7)], we obiain from Eqs. (8) and (14):

$$
N_{\text {Bi(d) }}=\frac{\left[N_{L i(m))^{4}}^{4}\right]\left[\gamma_{L_{3} B i(m)}^{\prime}\right]}{\left[3 \gamma_{L_{3} B i(d)}\right]} .
$$

If the ratio of the activily coefficients were constant, plots of $\log N_{B i(d)}$ vs. $\log N_{\text {Li(m) }}$ would we cxpected io yicld lines of slope 4. Plots of this type did not give a good represenicrition of the data. However, analysis of the data showed that, if $\gamma_{\mathrm{Li}_{3} \mathrm{Bi} \text { (d) }}$ were cissumed to be independent of concentration at each temperature, the activity coefficient for $\mathrm{Li}_{3} \mathrm{Bi}$ in the alloy phase could be expressed as

$$
\log \gamma_{L_{3} B i(m)}^{\prime}=A+1.12 N_{L i(m)}
$$

and that A varied with temperature as follows:

$$
A=\exp \left[-3.321+3090 / T\left({ }^{\circ} \mathrm{K}\right)\right]
$$

Air a given iemperaiure, $\gamma_{\mathrm{Li}_{3} \mathrm{Bi}(\mathrm{m})}^{\mathrm{d}}$ does not change markedly over a wide range of values of $\mathrm{N}_{\mathrm{Li}(\mathrm{m})}$. For example, af $800^{\circ}, \gamma_{\mathrm{Li}_{3} B i(m)}^{\prime}$ increases only from about 6 to 21 as $\mathrm{N}_{\mathrm{Li}(\mathrm{m})}$ increases from 0.1 to 0.6. Ey combining Eqs. (15), (16), and (17) with the equation presented carlice for the temperature dependence of $\log \gamma_{\mathrm{Li}_{3} \mathrm{Bi}(\mathrm{d})}$, we obtain the following generol 


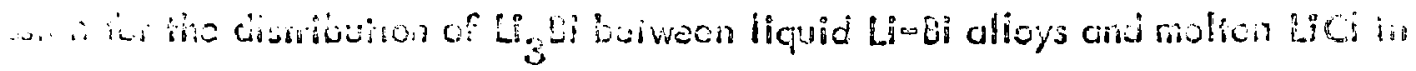

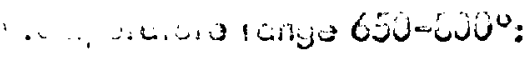

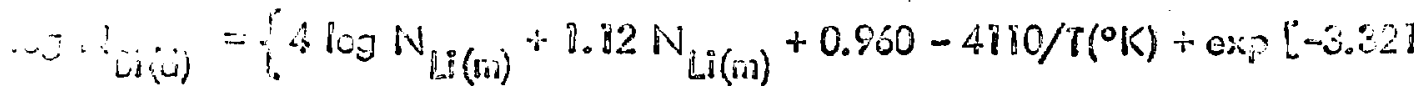

$$
\begin{aligned}
& +5090 / 1(\%)]\}=0,03
\end{aligned}
$$

. wi cacin lempercirure.

Wie conclude that the closerved distribution of lithiun and bismurh berween liguid Li - il alloys aid motren $\mathrm{LiCl}$ is cive to the distribution of $\mathrm{Li}_{3} \mathrm{Bi}$, and not the respective clomenis, Beiween fine iwo phases. If should be emphasized that the success of our models in describing the disiribution does nor constivite proof that the species cisumed were cuivalify firoso present. Additional experimeniation would be required to confirm the cisience of thrse species in the respecrive phases.

Acknowlodgmenis. The authors thank J. F. Land and C. T. Thompson for conduciing the experimenial work. Analyses were provided by W. R. Laing, J. L. Botts, N. Marion Gerguson, and G. Goldberg of the ORNL Analytical Chemistry Division. The authers exiend special thanks to J. Braunstein, ORNL Reactor Chemistry Division, for many helpful ciscussions and his critical review of the manuscript. 


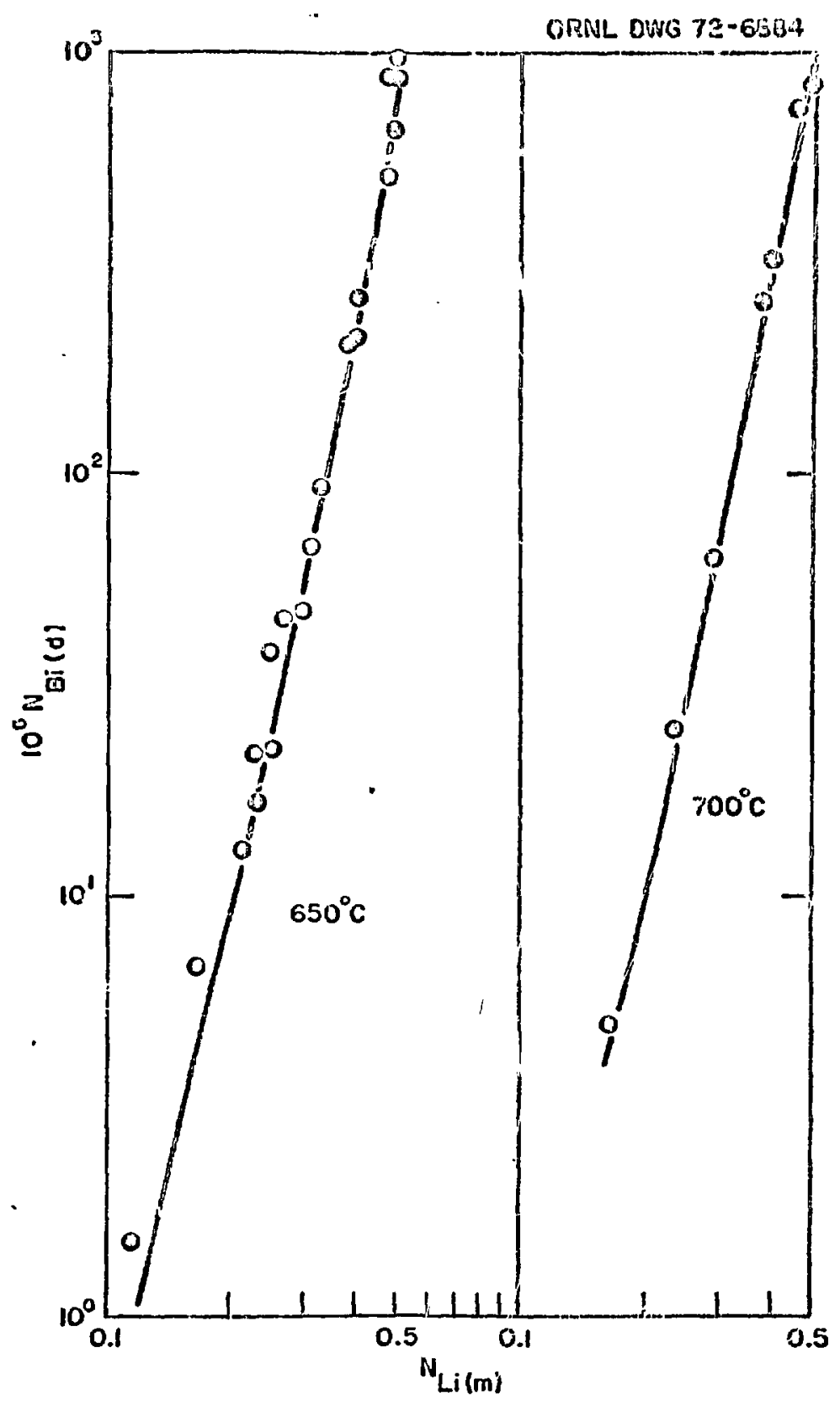

EQUHL IBRIUIA DISTRIBUTION OF Li ${ }_{3}$ BIT BETWEEN L.IQUID Li-Bi ALLOYS AND MOLTEN LiSI. CUEYVES CRLCIULATED FROH EQ. (18), WHICH WAS DERIVED FROM A MODEL ASSUUNING RANDOM MIXING OF $\mathrm{Li}^{+}, \mathrm{Bi}^{3-}$. ANO $B i^{\circ}$ IN THE ALLOY PHASE.

Figure 5 . 


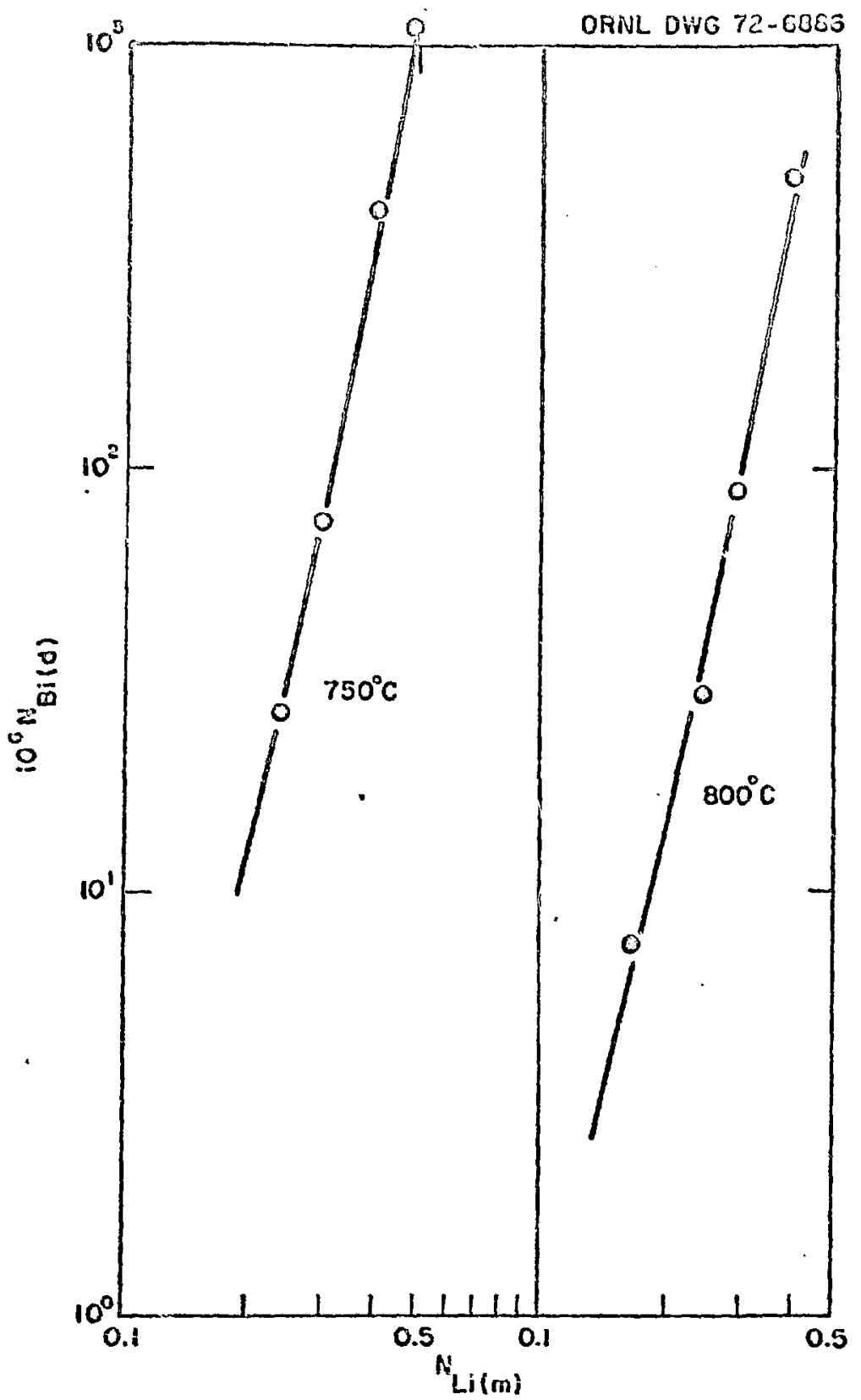

EQUILIERIUM DISTRIBUTION OF $\mathrm{Li}_{3}$ Bi BETWEEN LIOUID Li- $\mathrm{C} I$ ALLOYS AND MOLTEN LICI. CURVES CALCULATED FROM EQ. (18), WHCH WAS DERIVED FROA A MODEL ASSUMING RANDOM MIXING OF $\mathrm{Li}^{+}, B \mathrm{i}^{3}$; $A N D B \mathrm{i}^{\circ}$ IN $\mathrm{THE}$ ALLOY PHASE.

Figure 6. 
3. E. L. Irlciveese, MSR Program Semicinnu. Progr. Rep. Feb. 28, 1971, USAEC Rep. ORNL-46\%ó, p. 234.

$\therefore$ D. E. Ferguson and Staff, Chem. Technol. Div. Annu. Progr. Rep. Mar. 3i, 1971, USAEC ReP. ORNL-4682, p. 2.

3. M. A. Bredig, MSR Program Semiannu. Progr. Rep. Alng. 31, 1970, USAEC Rep. ORNL-4622, p. 85 .

4. E. R. Youngblood and L. E. McNeese, MSR Program Semiannu. Progr. Rep. Aug. 31, 1971, USAEC Rep. ORNL -4728, p. 202.

5. M. S. Fosier, C. E. Crouthamel, D. M. Gruen, and R. L McBeth, J. Phys. Chem. $68,980(1964)$.

G. E. J. Cairns, C. E. Crouthamel, A. K. Fischer, M. S. Foster, J. C. Hesson, C. E. Johnson, H. Shimotake, and A. D. Tevebaugh, Galvanic Cells with Fused-Salt Elecirolytes, USAEC Rep. ANL-7316 (1967), p. 119.

7. L. M. Ferris, J. C. Mailen, J. J. Lawrance, F. J. Smith, and E. D. Nogueira, J. Inorg. Nucl. Chem. 32, 2019 (1970).

8. M. Hansen and.K. Anderko, Constitution of Binary Alloys, McGraw-Hill, New York, 1958, p. 316.

9. L. M. Ferris and J. F. Land, MSR Program Semiannu. Progr. Rep. Aug. 31, 1971, USAEC Rep. ORNL-4728, p. 192.

10. M. S. Foster, S. E. Wood, and C. E. Crouthamel, Inorg. Chem. 3, 1428 (1964).

11. A. S. Dworkin, H. R. Bronstein, and M. A. Bredig, J. Phys. Chem. 66, 572 (1962). 


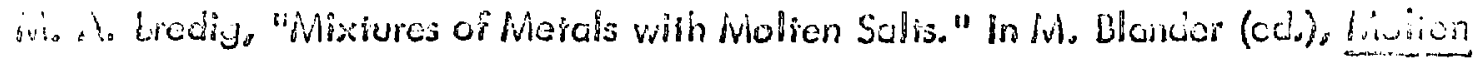

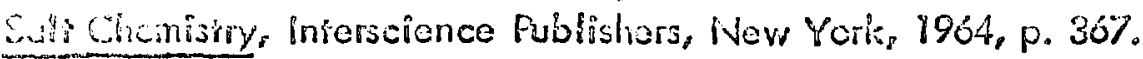

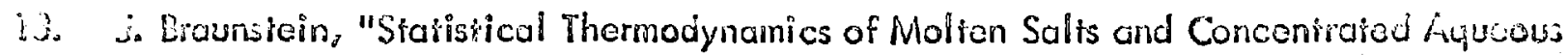
Elecirolyies." In S. Pefrucci (ed.), lonic Interaciions, Vol. I, Academic Press, New Yoik, 197i, p. 180.

34. M. Okada, R. A. Guidotti, and J. D. Corbett, Inorg. Chem. 7, 2118 (1968). 15. A. K. Fischer, S. A. Johnson, and S. E. Wood, J. Phys. Chenn. 71, 1465 (1967). 